\title{
Kandungan Logam Berat Timbal (Pb) Dan Tembaga (Cu) Pada Akar Dan Buah Mangrove Avicennia marina Di Perairan Tanjung Emas Semarang
}

\author{
Endang Supriyantini* dan Nirwani Soenardjo \\ Jurusan Ilmu Kelautan, Fakultas Perikanan dan Ilmu Kelautan, Universitas Diponegoro \\ JI. Prof. Soedarto, SH. Kampus UNDIP Tembalang, Semarang 50275 \\ Email : supri_yantini@yahoo.com
}

\begin{abstract}
Abstrak
Perairan Tanjung Emas merupakan salah satu kawasan pesisir yang dekat dengan aktivitas pelabuhan, industri, dan pemukiman penduduk. Tingginya aktivitas di kawasan Tanjung Emas diduga mengalirkan berbagai limbah yang dapat menimbulkan pencemaran, antara lainpencemaran oleh logam berat $\mathrm{Pb}$ dan $\mathrm{Cu}$. Penelitian ini bertujuan untuk mengetahui kandungan logam berat $\mathrm{Pb}$ dan $\mathrm{Cu}$ dalam air, sedimen, akar, dan buah mangrove Avicennia marinaserta untuk mengetahui tingkat akumulasi terhadap logamlogam tersebut. Metode yang digunakan dalam penelitian ini adalah metode deskriptif dan penentuan lokasi penelitian dilakukan dengan metode purposive sampling. Kemudian logam berat dianalisis menggunakan AAS (Atomic Absorbtion Spectrophotometry). Hasil penelitian menunjukan bahwa kandungan logam berat $\mathrm{Pb}$ dan $\mathrm{Cu}$ di perairan Tanjung Emas Semarang menunjukkan pencemaran berat karena sudah melebihi batas ambang yang ditentukan yaitu masing-masing 0,01-0,06 mg/L (Pb) dan 0,004-0,14 mg/L (Cu). Kandungan Cu pada sedimen sebesar 1,236-3,212 mg/kg; Cu pada akar2,104-2,529 mg/kg; dan Cu pada buah A. marina 1,640-4,336 mg/kg. Hampir semua hasil ini lebih tinggi bila dibandingkan dengan kandungan $\mathrm{Pb}$ pada sedimen 0,251-0,507 $\mathrm{mg} / \mathrm{kg}$; $\mathrm{Pb}$ pada akar 0,732-1,625 mg/kg; dan $\mathrm{Pb}$ pada buah A. marina 0,114-0,345 mg/kg.BCF akar tertinggi ditemukan pada logam $\mathrm{Pb}$ yaitu 1,443-6,474 dan TF buah tertinggi ditemukan pada logam Cu yakni 0,674-1,714.
\end{abstract}

Kata Kunci : Logam Berat Pb dan Cu, kolom air,sedimen, akar dan buah A.marina, BCF dan TF A. marina.

\begin{abstract}
Tanjung Emas waters were one of the coastal areas near that port activities, industries, and residential areas. The high activities in the area of Tanjung Emas allegedly flowed various wastes that can cause pollution, that is heavy metal $\mathrm{Pb}$ and $\mathrm{Cu}$. The aim of this research was to determine the content of heavy metals $\mathrm{Pb}$ and $\mathrm{Cu}$ in the waters, sediment, roots, and fruits of the mangrove Avicennia marina as well as to determine the level of accumulation for these metals. The method that was used in this research was descriptive method and the determination of the location of research area used purposive sampling method. Then, heavy metals were analysedusing AAS (Atomic Absorption Spectrophotometry). The results showed that the content of heavy metals $\mathrm{Pb}$ and $\mathrm{Cu}$ in the waters of Tanjung Emas Semarang showed heavy contamination because it exceeds thespecifiedthreshold is 0,01$0,06 \mathrm{mg} / \mathrm{L}(\mathrm{Pb})$ and 0,004-0,14 mg/L (CU). The content of $\mathrm{Cu}$ in the sediments was 1,236-3,212 $\mathrm{mg} / \mathrm{kg}$; Cucontentat the root was 2,104-2,529 mg/kg; and Cu content in fruits of mangrove A. marina is $1,640-4,336 \mathrm{mg} / \mathrm{kg}$. Almost all of these results was higher when compared with the content of $\mathrm{Pb}$ in sediments is $0,251-0,507 \mathrm{mg} / \mathrm{kg}$; $\mathrm{Pb}$ at the root is $0,732-1,625 \mathrm{mg} / \mathrm{kg}$; and $\mathrm{Pb}$ in A. marina fruits is $0,114-0,345 \mathrm{mg} / \mathrm{kg}$. The BCF highest root was found in $\mathrm{Pb}$ is 1,443-6,474 and TF highest fruits found on the committal was 0,674-1,714.
\end{abstract}

Keywords : Heavy Metal Pb and CU, in waters, Sediment, Roots and Fruit of A. marina, BCF and TFA. marina 



\section{PENDAHULUAN}

Perairan Tanjung Emas merupakan salah satu kawasan pesisir yang dekat dengan aktivitas pelabuhan, industri, dan pemukiman penduduk.Tingginya aktivitas di kawasan Tanjung Emas diduga mengalirkan berbagai limbah yang dapat menimbulkan pencemaran, diantaranya adalah limbah yang mengandung logam berat.

Mangrove yang tumbuh di muara sungai merupakan tempat penampungan bagi limbah-limbah yang terbawa aliran sungai.Mangrove memiliki kemampuan menyerap bahan-bahan organik dan non organik dari lingkungannya ke dalam tubuh melalui membrane sel. Proses ini merupakan bentuk adaptasi mangrove terhadap kondisi lingkungan yang ekstrim (Mastaller, 1996).Melalui akarnya, vegetasi ini dapat menyerap logam-logam berat yang terdapat pada sedimen maupun kolom air (Amin, 2001). Oleh karena ituA. marina dapat digunakan sebagai indikator biologis lingkungan yang tercemar logam berat.

Logam berat adalah unsur logam yang mempunyai massa jenis lebih besar dari $5 \mathrm{~g} / \mathrm{cm}^{3}$ (Subowo et al., 1999). Logam berat merupakan zat pencemar yang berbahaya karena memiliki sifat tidak dapat terdegradasi secara alami dan cenderung terakumulasi dalam air, sedimen dasar perairan, dan tubuh organisme (Harun et al., 2008). Adanya kegiatan industri dan pelabuhan di Perairan Tanjung Emas Semarang diduga menjadi penyumbang masuknya limbah berupa logam berat khususnya Timbal $(\mathrm{Pb})$ dan Tembaga (Cu) ke perairan Tanjung Emas Semarang.

Mekanisme yang terjadi pada $A$. marina untuk mengurangi toksisitas logam berat adalah menyimpan banyak air sehingga dapat mengencerkan konsentrasi logam berat dalam jaringan tubuhnya. Spesies ini dapat dikembangkan sebagai pengendalian pencemaran logam berat di wilayah pesisir dan dapat juga digunakan sebagai pollutant trap. Menurut Amin (2001) tumbuhan Avicennia marina mampu menyerap logam berat $\mathrm{Pb}$ pada bagian akar dan melokalisasikan ke bagian lain seperti daun dan buah.

Masyarakat pesisir Kota Semarang sudah memanfaatkan buah mangrove $A$. marina sebagai bahan pangan seperti bolu, kue, stik, peyek, kerupuk, dan lain sebagainya. Sedangkan, referensi mengenai konsentrasi logam berat $\mathrm{Pb}$ dalam buah mangrove A.marina di pesisir Kota Semarang masih sangat sedikit, sehingga perlu dilakukan penelitian mengenai "Kandungan Logam Berat Timbal (Pb) dan Tembaga (Cu) pada Akar dan Buah Mangrove A. marina di Perairan Tanjung Emas Semarang". Tujuan dari penelitian ini adalah untuk mengetahui kandungan logam berat $\mathrm{Pb}$ dan $\mathrm{Cu}$ khususnya pada jaringan akar dan buah mangrove A. marina. Penelitian ini penting karena apabila logam berat tersebut terpapar dalam jumlah yang tinggi pada manusia dikhawatirkan akan mengakibatkan gangguan dalam metabolisme dan terhambatnya pertumbuhan bahkan kematian.

\section{MATERI DAN METODE}

Materi yang digunakan dalam penelitian ini adalah air, sedimen, akar, dan buah mangrove Avicennia marina yang diambil dari Perairan Tanjung Emas Semarang.

Metode yang digunakan dalam penelitian ini adalah metodedeskriptif dan metode penentuan lokasi dalam penelitian ini adalah Purposive Sampling. Pengambilan sampel dilakukan ditiga lokasi yang berbeda, yaitu muara (stasiun 1), pemukiman (stasiun 2), dan pelabuhan (stasiun 3). Lokasi ini dipilih atas dasar adanya kegiatan industri, aktifitas pelabuhan, aktifitas manusia, dan terdapat sungai Banjir Kanal Timur di sekitarnya. Lokasi pengambilan sampel ditentukan dengan menggunakan alat bantu GPS dan lokasi penelitian disajikan pada Gambar 1.

Penelitian ini dilakukan pada bulan Desember 2014 - Januari 2015 di Perairan Tanjung Emas, Semarang.Pengambilan 
sampel dilaksanakan pada tanggal 7 Desember 2014. Analisis kandungan logam berat dilakukan di Balai Laboratorium Kesehatan Provinsi Jawa Tengah, Semarang dan Analisis ukuran butir sedimen dianalisis di Laboratorium Mekanika Tanah, Jurusan Teknik Sipil FT Undip, Semarang.

Sampel air diambil pada setiap lokasi penelitian dengan tiga kali ulangan masing-masing sebanyak $500 \mathrm{ml}$ pada kedalaman $\pm 30 \mathrm{~cm}$ dari permukaan air.Sampel air kemudian dimasukkan ke dalam botol sampel dan diawetkan dengan menambahkan larutan asam nitrat (HNO3) sampai $\mathrm{pH}<2$ (Rochyatun et al., 2006). Selanjutnya, sampel air diberi label dan dimasukan ke dalam cool box.

Sampel sedimen diambildengan menggunakan pipa paralon. Pipa tersebut berdiameter $\pm 5 \mathrm{~cm}$ dengan panjang \pm 30 $\mathrm{cm}$. Sampel sedimen diambil pada tiap stasiun penelitian dengan tiga kali pengulangan masing-masing sebanyak 1 $\mathrm{kg}$, kemudian sampel dimasukkan ke dalam plastik sampel dan diberi label.
Sampel akar mangrove yang digunakan dalam penelitian ini adalah akar pohon A. marinayang berada di dalam substrat.Sampel akar diambil menggunakan pisau atau cutter, dan pengambilan sampel dilakukan pada setiap stasiun dengan tiga kali pengulanganmasing-masing sebanyak 100 gram.Sampeldibersihkan dengan menggunakan air dan dipotong-potong ukuran panjang sekitar $\pm 10 \mathrm{~cm}$, kemudian dimasukkan dalam plastic dan diberi label.

Sampel buahmangrove yang digunakan dalam penelitian ini adalah buah A. marinayang sudah tua, dengan ciri-ciri buah berwarna hijau tua, panjang buah $\pm 2-2,5 \mathrm{~cm}$ dan lebar buah $\pm 1,5-2 \mathrm{~cm}$. Sampel buah diambil pada setiap stasiun dengan tiga kali pengulangan masingmasing diambil sebanyak \pm 100 gram.

Pengukuran parameter perairan secara insitu berupa suhu, salinitas, $\mathrm{pH}$, dan DO, dilakukan bersamaan dengan pengambilan sampel air, sedimen, akar, dan buah A.marinadengan tiga kali pengulangan pada setiap stasiun.
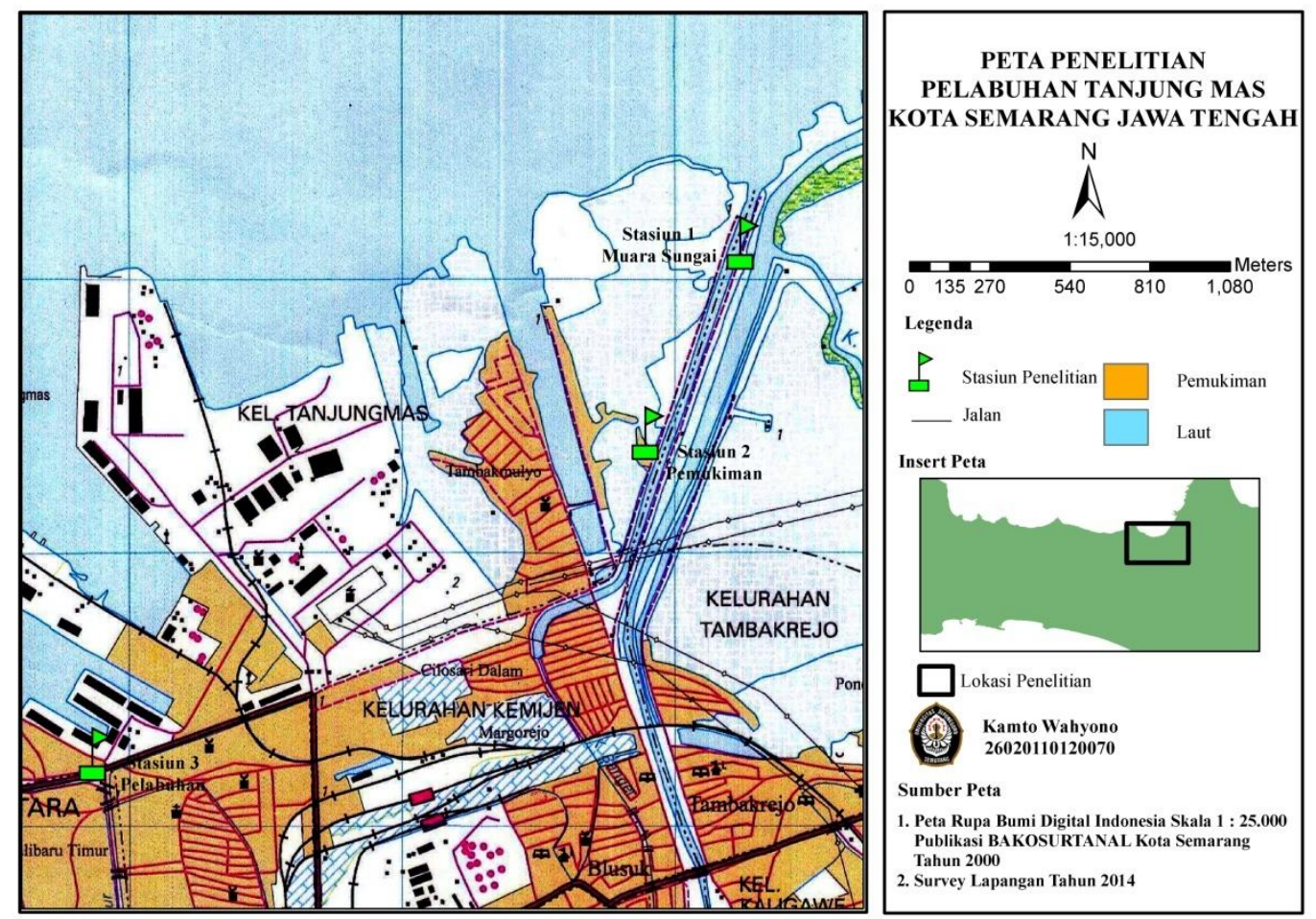

Gambar 1. Peta Lokasi Penelitian di Perairan Tanjung Emas. 
Sampel Air, Sedimen, Akar, dan Buah Mangrove A.marinayang telah didapat kemudian dibawa ke Laboratorium untuk dianalisis konsentrasi logam berat Timbal (Pb) dan Tembaga (Cu) menggunakan cara digesti asam.

Cara ini bertujuan untuk mengurangi gangguan yang disebabkan oleh bahan organik, serta mengubah logam $\mathrm{Pb}$ dan $\mathrm{Cu}$ yang berasosiasi denganpartikulat menjadi ion logam bebas sehingga dapat ditentukan kadarnya dengan alat Atomic Absorption Spectrophotometer (AAS) (APHA, 1992).

Data-data mengenai kandungan logam berat $\mathrm{Pb}$ dan $\mathrm{Cu}$ dalam air, sedimen, akar, dan buah mangrove A.marina yang telah diketahui tersebut, kemudian digunakan untuk menghitung kemampuan akar A. marina dalam mengakumulasi dan translokasi logam berat $\mathrm{Pb}$ dan $\mathrm{Cu}$ melalui faktor biokonsentrasi (BCF) dan faktor translokasi (TF) (MacFarlane et al., 2007). BCF dan TF dapat dihitung dengan rumussebagai berikut:

$$
\begin{gathered}
\mathrm{BCF}=\frac{\text { Logam Berat } \mathrm{Pb} / \mathrm{Cu} \text { pada Akar atau Buah }}{\text { Logam Berat } \mathrm{Pb} / \mathrm{Cu} \text { pada Sedimen }} \\
\mathrm{TF}=\frac{\text { Logam Berat } \mathrm{Pb} / \mathrm{Cu} \text { pada Buah }}{\text { Logam Berat } \mathrm{Pb} / \mathrm{Cu} \text { pada Akar }}
\end{gathered}
$$

Keterangan:

Nilai BCF $>1000=$ Kemampuan Tinggi

$1000>$ BCF $>250=$ Kemampuan Sedang

$\mathrm{BCF}<250=$ Kemampuan Rendah

\section{HASIL DAN PEMBAHASAN}

Berdasarkan hasil penelitian sampel air, sedimen, akar, dan buah A. marinadi Perairan Tanjung Emas, Semarang hampir semuanya mengandung logam berat $\mathrm{Pb}$ dan Cu (Tabel 1). Kandungan logam berat $\mathrm{Pb}$ dan $\mathrm{Cu}$ di perairan tersebut sudah termasuk kedalam tingkat pencemaran berat, karena kandungan logam berat $\mathrm{Pb}$ dan $\mathrm{Cu}$ telah melebihi batas ambang kandungan logam berat alamiah di perairan laut yaitu 0,008 mg/L (Kepmen LH No. 51 Tahun 2004).Tingginya konsentrasi logam $\mathrm{Pb}$ dan $\mathrm{Cu}$ pada kolom air di Perairan Tanjung Emas tidak terlepas dari kondisi perairan tersebut, yang banyak dipengaruhi oleh buangan limbah rumah tangga dan merupakan jalur transportasi kapal-kapal yang menggunakan bahan bakar yang dapat menambah kandungan $\mathrm{Pb}$ dan $\mathrm{Cu}$ di perairan.

Hal ini sesuai dengan pendapat Palar (1994) yang menyatakan bahwa aktivitas manusia, industri galangan kapal dan berbagai aktivitas pelabuhan lainnya merupakan salah satu jalur yang mempercepat terjadinya peningkatan kelarutan logam dalam badan air.Kandungan logam berat $\mathrm{Pb}$ di air secara umum lebih tinggi yaitu 0,01-0,06 $\mathrm{mg} / \mathrm{L}$ dibandingkan dengan logam $\mathrm{Cu}$ yaitu $\leq$ 0,004-0,14 mg/L. Hal ini diduga karena logam $\mathrm{Cu}$ biasanya terikat kuat pada bahan organik akan menurunkan mobilitasnya di perairan sehingga akan lebih mudah mengendap di sedimen.

Secara umum kandungan logam berat baik $\mathrm{Pb}$, maupunCu dalam air memiliki nilai yang lebih rendah dibandingkan dengan yang ada di sedimen.Hal ini disebabkan karena logam berat mempunyai sifat yang mudah mengikat bahan organik dan mengendap di dasar perairan dan berikatan dengan partikel-partikel sedimen, sehingga konsentrasi logam berat dalam sedimen lebih tinggi dibanding dalam air (Hutagalung, 1991).Diperkuat oleh Wilson (1988), bahwa logam berat yang terlarut dalam air akanberpindah ke dalam sedimen jika berikatan dengan materi organik bebas atau materi organik yang melapisi permukaan sedimen, dan penyerapan langsung oleh permukaan partikelsedimen.

Selain itu rendahnya kandungan logam berat dikolom air diduga disebabkan pula olehfaktor curah hujanyang cenderung tinggi pada saat dilakukan penelitian. Berdasarkan hasil pantauan yang dilaporkan oleh Stasiun Meteorologi Maritim, Semarang pada bulan Desember 2014 rata-rata curah hujan per hari $8,06 \mathrm{~mm} /$ hari.Menurut Darmono(1995) kandungan logam berat dipengaruhi oleh lingkungan dan musim, pada musim hujan logam akan mengalami pelarutan sedangkan pada musim 
kemarau logamakan terkonsentrasi. Kondisi curah hujan ini akan mempengaruhi $\mathrm{pH}$ lingkungan perairan menjadi asam, hal ini terlihat pada hasil pengukuran $\mathrm{pH}$ di lapangan hampir di semua stasiun $\mathrm{pH}$ nya sekitar 6,33-6,96. Menurut Deri et al. (2013), $\mathrm{pH}$ asam akan meningkatkan potensi kelarutan logam berat.

Kandungan rata-rata logam timbal (Pb) dan tembaga (Cu) yang berada pada kolom perairan, sedimen,akar dan buah mangrove A. marina disajikan pada Gambar 2.

Kandungan logam berat $\mathrm{Pb}$ dan $\mathrm{Cu}$ dalam sedimen di Perairan Tanjung Emas masih dibawah batas ambang yang ditentukan oleh NOAA (Buchman, 1999). Namun demikian kandungan logam $\mathrm{Cu}$ di sedimen di semua stasiun hasilnya lebih tinggi jika dibandingkan dengan $\mathrm{Pb}$ yaitu berkisar antara 1,236-3,212 mg/kg (Cu) dan $0,251-0,507 \mathrm{mg} / \mathrm{kg}(\mathrm{Pb})$.

Perbedaan kandungan logam berat ini diduga disebabkan oleh faktor salinitas dan $\mathrm{pH}$ perairan. Berdasarkan hasil pengukuran salinitas di lapangan sebesar 18,33-25 \%o masih berada di bawah ambang batas yang ditentukan oleh
(Kepmen LH No. 51 Tahun 2004) yaitu 33-34 \%。 sedangkan $\mathrm{pH}$ cenderung asam yaitu 6,33-6,96. Menurut Hutagalung (1991), penurunan salinitas dan $\mathrm{pH}$ serta naiknya suhu menyebabkan tingkat bioakumulasi semakin besar karena ketersediaan logam berat tersebut semakin meningkat. Dijelaskan pula bahwa pada pH tinggi, bentuk-bentuk yang utama adalah hidroksida dengan kelarutan yang rendahdan pada $\mathrm{pH}$ rendah, ion-ion logam bebas yang sangat larut, mendominasi.

Perbedaan kandungan kedua logam tersebut diduga juga karena logam Cu merupakan logam berat yang cenderung mudah untuk terendapkan dalam sedimen, sehingga akumulasi logam Cu pada sedimen akan lebih tinggi dibandingkan logam $\mathrm{Pb}$. Seperti ditegaskan oleh Hutagalung (1991), bahwa kemampuan beberapa logam berat dalam berikatan dengan asam amino mengikuti urutan sebagai berikut: $\mathrm{Hg}>\mathrm{Cu}$ $>\mathrm{Ni}>\mathrm{Pb}>\mathrm{Co}>\mathrm{Cd}$, maka logam yang paling besar keberadaannya dapat diserap adalah logam $\mathrm{Cu}$, kemudian disusul logam $\mathrm{Pb}$. Kandungan logam $\mathrm{Pb}$ yang tidak essensial bagi kehidupan tumbuhan terakumulasi lebih sedikit di sedimen.

Tabel 1. Kandungan Rata-Rata ( $\mathrm{n}=3$ ) Logam Berat $\mathrm{Pb}$ dan $\mathrm{Cu}$ pada Air, Sedimen, Akar, dan Buah A. marinadi Perairan Tanjung Emas Semarang

\begin{tabular}{ccccc}
\hline Sampel & Stasiun & $\mathrm{Pb}$ & $\mathrm{Cu}$ & Baku Mutu \\
\hline Air & Muara & 0,010 & 0,140 & \\
$(\mathrm{mg} / \mathrm{L})$ & Pemukiman & 0,060 & $\leq 0,004$ & $0,008^{*}$ \\
& Pelabuhan & 0,040 & 0,010 & \\
\hline Sedimen & Muara & 0,403 & 2,971 & \multirow{3}{*}{$30,24^{* *}$} \\
$(\mathrm{mg} / \mathrm{kg})$ & Pemukiman & 0,507 & 3,212 & \\
& Pelabuhan & 0,251 & 1,236 & \\
\hline Akar & Muara & 0,833 & 2,529 & \\
$(\mathrm{mg} / \mathrm{kg})$ & Pemukiman & 0,732 & 2,104 & \\
& Pelabuhan & 1,625 & 2,430 & \\
\hline Buah & Muara & 0,164 & 4,336 & \\
$(\mathrm{mg} / \mathrm{kg})$ & Pemukiman & 0,114 & 2,111 & \\
& Pelabuhan & 0,345 & 1,640 & \\
\hline
\end{tabular}

* : Baku Mutu Parameter Perairan dan Air Laut Berdasarkan SK No. 51/Kementerian

Lingkungan Hidup (MENKLH)/Tahun 2004

** : Baku Mutu Sedimen Berdasarkan NOAA (Buchman, 1999) 


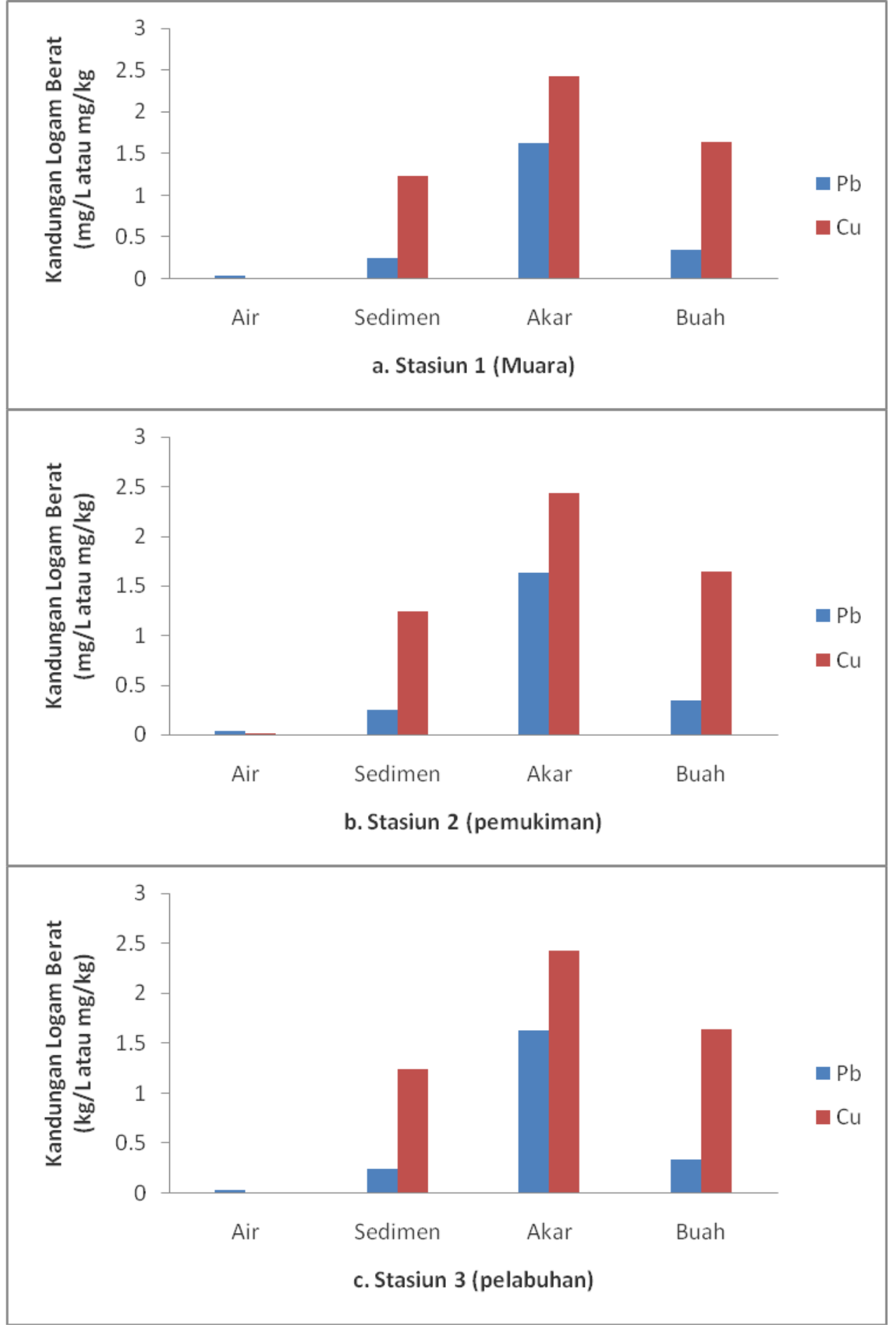

Gambar 2. Kandungan Rata-Rata Logam Berat Cu dan Pb

Berdasarkan hasil pengamatan, kandungan logam berat $\mathrm{Pb}$ dan $\mathrm{Cu}$ di sedimen pada stasiun 1 (muara) dan 2 (pemukiman) mempunyai kandungan logam berat lebih tinggi dibanding stasiun 3 (pelabuhan). Tingginya kandungan logam berat di Stasiun 1 dan 2 di dugaberkaitan dengan jenis sedimen dari masing-masing stasiun. Jenis sedimen di stasiun-1 dan 2 yang didominasi oleh silt ( lumpur) yaitu sekitar 87,59-91,41 \% lebih halus butirannya dibanding Stasiun-3 yang jenisnya sand (pasir) yaitu 73,77 \%. Menurut Sahara (2009), kandungan logam berat disedimen juga dipengaruhi oleh ukuran partikel sedimen. Semakin kecil ukuran 
partikel, semakin besar kandungan logam beratnya. Hal ini disebabkan karena partikel sedimen yang halus memiliki luas permukaan yang besar dengan kerapatan ion yang lebih stabil untuk mengikat logam berat daripada partikel sedimen yang lebih besar. Secara tidak langsung, nutrien dan zat hara yang terlarut dalam air pun dapat disimpan dengan baik sehingga sedimen halus umumnya memiliki kemampuan menyerap relatif lebihtinggi. Lain halnya dengan sedimenberbutir besar lebih mudah kehilangan kandungan bahan organik atau nutrien(Mc Lachlan dan Brown, 2006 dalam Tuheteru dan Mahfudz,
2012). Oleh sebab itu kandungan logam berat dalam sedimen di stasiun 1 dan 2 lebih tinggi bila dibanding stasiun 3 .

Hasil pengukuran parameter fisika kimia perairan dan analisis ukuran butir sedimen serta nilai BCF dan TF perairan Tanjung Emas Semarang disajikan pada Tabel 2, 3, dan 4.

Hasil penelitian menunjukkan bahwaakumulasi logam Pbdan Cu berbeda baik pada akar maupun buah. Akumulasi logam $\mathrm{Pb}$ pada akar lebih tinggi dibandingkan pada Cu.

Tabel 2. NilaiParameter Fisika Kimiaselama Penelitan di Perairan Tanjung Emas. Nilai dalam Kurung Menunjukkan Nilai Rata-Rata Kisaran Parameter $(n=3)$.

\begin{tabular}{ccccc}
\hline \multirow{2}{*}{ Parameter } & \multirow{2}{*}{ Muara } & \multicolumn{2}{c}{ Stasiun } & \\
\cline { 3 - 4 } & & Pemukiman & Pelabuhan & Baku Mutu* \\
\hline Suhu $\left({ }^{\circ} \mathrm{C}\right)$ & $27-33$ & $25-26$ & $27-31$ & $28-32$ \\
& $(29,06)$ & $(25,66)$ & $(29,73)$ & \\
$\mathrm{DH}$ & $6,0-8,9$ & $6,0-7,0$ & $6,0-7,0$ & $7-8,5$ \\
& $(6,96)$ & $(6,66)$ & $(6,33)$ & $>5$ \\
DO $(\mathrm{mg} / \mathrm{L})$ & $6,2-6,8$ & $6,2-6,8$ & $1,1-7,4$ & \\
& $(6,50)$ & $(6,46)$ & $(3,63)$ & $33-34$ \\
\hline
\end{tabular}

*Keputusan Menteri Negara Lingkungan Hidup No. 51 Tahun 2004.

Tabel 3. Hasil Analisis Ukuran Butir Sedimen di Perairan Tanjung Emas, Semarang

\begin{tabular}{ccccc}
\hline \multirow{2}{*}{ Stasiun } & \multicolumn{4}{c}{ Ukuran Butir(\%) } \\
\cline { 2 - 5 } & Gravel & Sand & Silt & Clay \\
\hline 1 & 0.00 & 9,70 & 87,59 & 2,71 \\
2 & 2,98 & 2.90 & 91,41 & 2,71 \\
3 & 12,79 & 73,77 & 13,44 & 0,00 \\
\hline
\end{tabular}

Tabel 4. Nilai Faktor Biokonsentrasi (BCF) dan Faktor Translokasi (TF) Logam Pb dan Cu

\begin{tabular}{ccrrr}
\hline \multirow{2}{*}{ Jenis Logam } & \multirow{2}{*}{ Stasiun } & BCF & TF \\
\cline { 3 - 5 } & Muara & 2,066 & 0,406 & 0,196 \\
$\mathrm{nyb}$ & Pemukiman & 1,443 & 0,224 & 0,155 \\
& Pelabuhan & 6,474 & 1,374 & 0,212 \\
& Muara & 0,851 & 1,459 & 1,714 \\
$\mathrm{Nu}$ & Pemukiman & 0,655 & 0,657 & 1,003 \\
& Pelabuhan & 1,966 & 1,326 & 0,674 \\
\hline
\end{tabular}


Perbedaan tersebut diduga disebabkan oleh proses masuknya logam $\mathrm{Pb}$ pada jaringan. Menurut MacFarlane dan Burchett (2002), Pb merupakan logam yang sangat rendah daya larutnya bersifat pasip dan mempunyai daya translokasi yang rendah mulai dari akar sampai organ tumbuhan lainnya. Hal ini dapat dibuktikan dari nilai BCFPb dari sedimen ke akar nilainya lebih tinggi yaitu 1,4436,474dibandingkan dengan nilai BCF dari sedimen ke akar pada Cuantara0,6551,966.Selain itu karena A. marina ini merupakan jenis mangrove yang sangat ketat dalam proses penyerapan logam berat non essensial seperti $\mathrm{Pb}$. Menurut MacFarlane et al. (2003), mangrove secara aktif mengurangi penyerapan logam berat ketika konsentrasi logam berat di sedimen tinggi.

Berbeda dengan tingkat akumulasi yang terjadi pada logam Cu, nilai BCF dari sedimen ke akar cenderung lebih kecil bila dibanding pada buah. Hal ini diduga karena logam Cu yang ada pada sedimen diserap oleh akar mangrove dan kemudian didistribusikan pada bagian tumbuhan yang lain, termasuk juga buah. Hal ini dapat dilihat dari nilai TF pada Cu $(0,674-1,714)$ lebih tinggi dibanding TF pada $\mathrm{Pb}(0,155$ 0,212 ). Selain menyerap logam pada sedimen, akar-akar mangrove tersebut juga dapat menyerap logam yang terdapat pada kolom air, mengingat akar mangrove dapat terendam air saat air pasang. Mekanisme ini secara terperinci dijelaskan oleh Hardiani (2009), dimana secara umum tumbuhan melakukan penyerapan oleh akar, baik yang berasal dari sedimen maupun air, kemudian terjadi translokasi ke bagian tumbuhan yang lain dan lokalisasi atau penimbunan logam pada jaringan tertentu. Pada tumbuhan secara umum logam Cu merupakan logam esensial yang dibutuhkan tumbuhan untuk pertumbuhannya, yaitu sebagai activator enzim (Palar, 2004).

\section{KESIMPULAN}

Berdasarkan hasil penelitian, perairan Tanjung Emas Semarang tercemar berat oleh logam $\mathrm{Pb}$ dan $\mathrm{Cu}$ karena sudah melebihi batas ambang yang ditentukan. Sedangkan kandungan logam Cu pada sedimen, akar dan buah mangrove $A$. marina lebih tinggi dibandingkan logam $\mathrm{Pb}$. Nilai BCF akar tertinggi ditemukan pada logam $\mathrm{Pb}$ dan nilai TF buah tertinggi ditemukan pada logam Cu. Kemampuan A. marina dalam mengakumulasi logam berat $\mathrm{Pb}$ dan $\mathrm{Cu}$ dikategorikan rendah

\section{DAFTAR PUSTAKA}

Amin, B. 2001. Akumulasi dan Distribusi Logam Berat $\mathrm{Pb}$ dan $\mathrm{Cu}$ padaMangrove (Avicennia marina) di Perairan Pantai Dumai, Riau. JurnalNatur Indonesia Vol. 4(1): 80-86.

[APHA] American Public Health Association, American Water Works Association and Water Pollution Control Federation. 1992. Standart Method for The Examination of Water and Wastewater. $18^{\text {th }}$ edition. Washington, $2552 \mathrm{p}$.

Buchman, M. 1999. Ilmu Tanah. Gajah Mada University Press, Yogyakarta.

Darmono. 1995. Logam dalam Sistem Biologi Makhluk Hidup. Penerbit Universitas Indonesia. Jakarta. $121 \mathrm{hlm}$.

Deri, Emiyarti dan L. O. A. Afu. 2013. Kadar Logam Berat Timbal (Pb) padaAkar Mangrove Avicennia marina di Perairan Teluk Kendari. JurnalMina Laut Indonesia, Jurnal Mina Laut Indonesia. vol. 01 No. 01: 38-48.

Hardiani H. 2009. Potensi Tanaman Dalam Mengakumulasi Logam Cu Pada Media Tanah Terkontaminasi Limbah PadatIndustri Kertas. Berita Selulosa 44(1) : 27-40.

Harun, N.H., Tuah P.M., Markom M.Z., Yusof M.Y. 2008. Distribution Of Heavy Metals In Monochoria hastata and Eichornia crassipes In Natural Habitats. Environmental Science Programme School of Science and Technology, University of Malaysia.

Hutagalung, H.P. 1991. Pencemaran Laut Oleh Logam Berat dalam Beberapa PerairanIndonesia. Puslitbang. Oseanologi LIPI. Jakarta. HIm 45 - 59.

Keputusan Menteri Negara Lingkungan Hidup. 2004. Keputusan Menteri Negara Lingkungan Hidup No: 
51/MNKLH/1/2004 tentang pedoman penetapan baku mutu air laut. Menteri Lingkungan Hidup. Jakarta. 6-7 hlm.

MacFarlane, G.R., and M.D. Burchett. 2002. CellularDistribution of Copper, Lead and Zinc inthe Grey MangroveAvicennia marina (Forsk.) Vierh. Aquatic Botany 68: 45- 59.

MacFarlane,G.R. 2003. Accumulation And Distribution of Heavy Metal In The Grey Mangrove Avicennia marina. Marine Pollution Bulletin Vol 39 : 179-186.

MacFarlane, G.R., E.C. Koller, and S.P. Blomberg. 2007. Accumulation and Patitioning of Heavy Metals in Mangrove: A Synthesis of Field-based Studies. Chemosphere. 1454-1464 pp.

Mastaller, M. 1996. Destruction of Mangrove Wetlands-Causes and Consequences A Biannual Collection Titled Natural Resources and Development Focus; Mangrove Forest, Institute for Scientific Cooperation, Tobingen.

Palar, H. 1994. Pencemaran dan Toksikologi Logam Berat. Cet: 2. PT. Rineka Cipta, Jakarta.
2004. Toksikologi dan Pencemaran Logam Berat. Rineka Cipta. Jakarta.

Rochyatun E., M.T. Kaisupy, dan A. Rozak. 2006. Distribusi Logam Berat dalam Air dan Sedimen di Perairan Muara Sungai Cisadane. Makara Sains. 10(1): 35-40 hlm.

Sahara, E. 2009. Distribusi Pb dan Cu pada Berbagai Ukuran Partekel Sedimen di Pelabuhan Benoa. Jurnal Kimia 3 (2) : 75-80 hlm.

Subowo, M.S., Widodo, dan A. Nugraha.1999. Status dan Penyebaran $\mathrm{Pb}, \mathrm{Cd}$, dan Pestisida pada Lahan Sawah Intensifikasi di Pinggir Jalan Raya. Prosiding. Bidang Kimia dan Bioteknologi Tanah, Puslittanak, Bogor.

Tuheteru F.D dan Mahfudz.2012. Ekologi, Manfaat \& Rehabilitasi,Hutan Pantailndonesia. Balai Penelitian Kehutanan Manado. Manado, Indonesia. 178 hal.

Wilson. 1988.Wilson, J. G., 1988. The Biology of Estuarine Management Croom Helm. London 